\title{
ПРАВО НА СОЦАЛЬНИЙ ЗАХИСТ ТРАНСГЕНДЕРНИХ ЛЮДЕЙ ЗА ЗАКОНОДАВСТВОМ УКРАЇНИ ТА ОКРЕМИХ ЗАРУБІЖНИХ КРАЇН
}

\author{
Волошина С. М., Бориченко К. В.
}

\section{ВСТУП}

3 розвитком медицини все більшої актуальності набувають питання зміни статі. Так, перша відповідна операція, про яку офіційно було поінформовано громадськість, була проведена в 1953 р. в Данії - американець змінив чоловічу стать на жіночу. У Союзі Радянських Соціалістичних Республік в 1970 р. у Ризі професором В. Калнберзом була проведена операція зміни статевої належності жінці. У сучасних умовах лідирує в даній сфері Таїланд. У Сполучених Штатах Америки (далі - США) приблизно 12 тис. хірургів проводять операції зі зміни (корекція) статевої належності ${ }^{1}$.

Проте правове регулювання даного процесу в Україні та більшості закордонних країн значно відстає від реальних потреб сучасності. Питання гендерної ідентичності суперечать моральним, духовним, релігійним переконанням багатьох людей. Крім того, з розвитком концепції прав і свобод особистості, яка включає право на зміну статі в нову групу прав і свобод - соматичні права, набула актуальності проблема узгодження реалізації відповідного права з іншими правами людини, зокрема й права на соціальний захист.

Спершу доцільно зауважити, що поняття «гендерна ідентичність» об'єднує в собі дві частини: 1) право на зміну (корекцію) біологічної статі; 2) право на зміну соціальної статі ${ }^{2}$. Зміна соціальної статі фактично $\epsilon$ проявом самовираження, що не передбачає обов'язкового медичного втручання в організм людини, отже, і практично жодних юридичних наслідків, зокрема у сфері соціального захисту, не спричиняє. Людина ж, чия біологічна стать скоригована, зокрема й із застосуванням хірургічних методів, $є$ трансгендерною. Здійснення іiі права на соціальний захист та права на соціальний захист членів іiі сім’і в такому разі може бути ускладнене.

\footnotetext{
1 Малеина М. Изменение биологического и социального пола: перспективы развития законодательства. Сейчас.ру : бизнес-издание. Новости России и мира. 2017. URL: https://www.lawmix.ru/ comm/4721.

${ }^{2}$ Шалиганова А. Щодо правової природи та змісту права на гендерну ідентичність. Право $і$ безпека. 2011. № 3 (40). С. 276.
} 
Варто зазначити, що дискомфорт, пов'язаний із розбіжністю між статевою ідентичністю людини і статтю, встановленою щодо неї за народження, не є рідкістю. Опитування, проведене у 2012 р. Комісією 3 прав людини та рівності у Сполученому Королівстві Великобританії, показало, що більше $1 \% 3 \quad 10000$ респондентів ідентифікували себе відмінною від вродженої статтю. У Російській Федерації, за неофіційними даними, станом на 2017 р. налічувалося 110 тис. чоловіків, які змінили стать на жіночу, і більше 240 тис. жінок, які змінили стать на чоловічу ${ }^{3}$.

Єдину міжнародну статистику, яку можна умовно вважати офіційною, надало Співтовариство пластичних хірургів США (ASPS). Так, за даними спеціалістів, у 2015 р. було проведено 3256 «транс-чоловічих» і «трансжіночих» операцій. Кількість чоловіків, які наважилися на операцію зі зміни (корекції) статевої належності, вища на 54\%, ніж жінок. Звичайно, результати відповідних досліджень не можна вважати визначальними та такими, що характеризують проблему гендерної ідентичності однаково в усіх країнах світу, але в Україні аналогічні опитування не проводились, офіційна статистика взагалі відсутня, тому спростувати відповідні цифри неможливо.

Цікаво, що тривалий проміжок часу в міжнародній i національній медичній класифікації транссексуальність визначалася як психічний розлад, що було своєрідною перешкодою на шляху до реалізації прав трансгендерними особами, зокрема й щодо проведення зміни (корекції) гендерної належності, та ставало підгрунтям для визнання таких людей недієздатними й у зв'язку із цим унеможливлення самостійно вливати на обсяг медичної допомоги, що буде надаватися. Комісар Ради Свропи з прав людини зазначив: «3 погляду прав особи й охорони здоров'я немає необхідності встановлювати діагноз психічного розладу для забезпечення доступу до лікування в умовах, коли потрібна медична допомога». Саме тому у 2018 р. транссексуальність видалили 3 переліку психіатричних захворювань, віднесли ії до захворювань, пов'язаних із розладами статевої ідентифікації.

Фактично, виходячи 3 європейських стандартів прав людини, право трансгендерних осіб на зміну (корекцію) статевої належності $є$ проявом права на повагу до приватного і сімейного життя, гарантованого ст. 8 Конвенції про захист прав людини і основоположних свобод 1950 р. Органи державної влади повинні утримуватися від втручання у відповідне право, забезпечити індивіду право на повсякденне життя без нагляду та контролю за його діяльністю з боку держави.

\footnotetext{
3 Калайтанова Н. Смена пола. Повторный процесс социализации трансгендеров. Проблемы $u$ перспективы развития гуманитарных и социально-экономических наук : сборник научных трудов по материалам Международной научно-практической конференции. 2017. Ч. 3. С. 32.
} 
Європейський суд 3 прав людини встановив як позитивне зобов'язання для держав надання можливості хірургічного втручання для повної зміни статі та гендеру. Прецедентне право Європейського суду 3 прав людини (далі - ССПЛ) чітко вимагає від держав не тільки надати можливість проведення операції щодо повної зміни статі, але й передбачити в системах страхування загальне «необхідне 3 медичного погляду» лікування, частиною якого є хірургічна корекція тіла ${ }^{4}$. На відповідні рішення Суду 3 успіхом посилалися трансгендери в низці країн, наприклад, у Литві та Бельгії, щоб розширити сферу свого медичного страхування.

У розвиток практики ЄСПЛ 31 березня 2010 р. Комітетом міністрів Ради Свропи були ухвалені рекомендації CM/Rec (2010) 5, у яких відображені заклики до держав-членів ужити «відповідних заходів, щоб гарантувати повне визнання зміни будь-якою особою гендеру в усіх сферах життя, в тому числі шляхом забезпечення можливості оперативним, прозорим i доступним шляхом змінювати ім'я і гендер в офіційних документах» 5 .

\section{1. Реалізація права трансгендерних людей на медичну допомогу}

Україна закріпила правову можливість зміни статі на рівні закону. Так, у ст. 51 Основ законодавства про охорону здоров'я від 11 листопада 1992 р. передбачено, що на прохання пацієнта, відповідно до визначених медикобіологічних i соціально-психологічних показань, йому може бути проведено шляхом медичного втручання в закладах охорони здоров'я зміну (корекцію) його статевої належності.

Майже аналогічні за змістом положення закріплені у ст. 19 Закону Республіки Білорусь від 18 червня 1993 р. «Про охорону здоров'я», відповідно до якої зміна і корекція статевої належності проводяться за бажанням повнолітнього пацієнта в державних організаціях охорони здоров'я в порядку, визначеному Міністерством охорони здоров'я Республіки Білорусь.

Законодавство ж Російської Федерації (далі - РФ) взагалі не містить жодних положень, що визначають правила, підстави, умови та порядок проведення операцій щодо зміни (корекції) статевої належності, а також правовий статус осіб, яким такі операції були проведені. Так, Цивільний кодекс РФ, Сімейний кодекс РФ, Федеративний закон «Основи законодавства Російської Федерації про охорону здоров'я» від 22 липня 1993 р., Федеративний закон «Про психіатричну допомогу і гарантії прав

\footnotetext{
${ }^{4}$ Commissioned and published by Thomas Hammarberg. Council of Europe Commissioner for Human Rights. 29.07.2009. URL: https://wcd.coe.int/ViewDoc.jsp?p=\&id =1588227\&Site=COE\&direct=true.

5 Про заходи з боротьби проти дискримінації за ознаками сексуальної орієнтації або гендерної ідентичності : Рекомендація CM/Rec (2010) 5 Комітету міністрів Ради Європи державам-членам. Медичне право. 2014. № 1. С. 66-75.
} 
громадян за iii надання» від 2 липня 1992 р. відповідних норм не закріплюють. Лише у ст. 70 Федеративного закону «Про акти цивільного стану» від 15 листопада 1997 р. згадується про обов’язок органу актів цивільного стану внести зміни до актового запису цивільного стану в разі надання особою документа встановленої форми про зміну статі, виданого медичною організацією.

Водночас сам порядок видачі відповідного документа у РФ фактично не закріплений на законодавчому рівні. Так, тривалий проміжок часу в Російській Федерації діяли винятково Клінічні інструкції «Моделі діагностики і лікування психічних і поведінкових розладів», які закріплювали моделі діагностичних процедур та лікування психічних розладів, зокрема й транссексуалізму, які мали суто рекомендаційний характер та визначали доцільність амбулаторного лікування відповідних пацієнтів не менше двох років комплексом медичних заходів: психотерапією, фармакотерапією, хірургічною корекцією анатомічних статевих ознак.

В аспекті даного дослідження кардинально відрізняється досвід Аргентини в регулюванні відносин надання медичної допомоги трансгендерним особам. Так, у другій половині XX ст. хірургічна корекція статі в Аргентині могла бути здійснена лише на підставі судового рішення. Проте в середині 2012 р. Законом «Про гендерну ідентичність» було дозволено громадянам офіційно змінювати ім'я та їхню гендерну ідентичність, якщо вони цього хочуть, без спеціального дозволу суду. Гендерна ідентичність у вищеназваному Законі визначена як «внутрішнє й індивідуальне сприйняття людиною своєї статі, яке може як збігатися, так і не збігатися з біологічною статтю, яка була визначена за народження, включаючи особливий тілесний досвід». Громадянам Аргентини на рівні закону гарантовано право змінити стать хірургічним шляхом та внести відповідні зміни до документів, що посвідчують особу. Водночас висновок психіатричного закладу (психіатрична експертиза) для реалізації відповідного права не вимагається ${ }^{6}$

3 метою закріплення вимог до діагностичних, лікувальних, профілактичних та реабілітаційних методів надання медичної допомоги трансгендерним особам в Україні та послідовності їі надання для максимального покращення якості життя пацієнтів 15 вересня 2016 р. наказом Міністерства охорони здоров’я України № 972 було затверджено уніфікований клінічний протокол первинної, вторинної (спеціалізована) та третинної (високоспеціалізована) медичної допомоги «Гендерна дисфорія» ${ }^{7}$.

\footnotetext{
${ }^{6}$ Глобальних рух за гендерну рівність. Англійський переклад аргентинського Закону «Про гендерну ідентичність». URL: http://globaltransaction.files.wordpress.com/2012/05/argentina-gender-identity-law.pdf.

${ }^{7}$ Про затвердження та впровадження медико-технологічних документів зі стандартизації медичної допомоги при гендерній дисфорії : наказ Міністерства охорони здоров’я України від 15 вересня 2016 р. № 972. URL: https://dec.gov.ua/wp-content/uploads/2019/11/2016_972_ykpmd_gendysfor.pdf.
} 
Відповідно до даного нормативно-правового акта, гендерною дисфорією $\epsilon$ дискомфорт або дистрес, що пов'язані 3 розбіжністю між статевою ідентичністю індивіда і статтю, встановленою йому під час народження, i пов'язаною із цим гендерною роллю i/aбо первинними та вторинними статевим ознаками.

Для подолання / максимального пом'якшення відповідного дискомфорту / дистресу особам, яким встановлено діагноз «Гендерна дисфорія», надається медична допомога, що спирається на різні терапевтичні програмно-цільові підходи і має на меті: зміни гендерного самовираження і ролі (що може включати епізодичне або постійне життя в іншій гендерній ролі, що збігається 3 гендерною ідентичністю людини); фемінізацію або маскулінізацію тіла шляхом гормональної терапії; зміну первинних та/або вторинних статевих ознак (наприклад, грудей, зовнішніх та/або внутрішніх геніталій) шляхом хірургічної корекції; дослідження гендерної ідентичності, ролі і самовираження; роботу з негативним впливом гендерної дисфорії і стигми на психічне здоров'я; полегшення внутрішньої трансфобії; збільшення соціальної підтримки та взаємодопомоги; поліпшення образу тіла або розвитку стресостійкості шляхом психотерапії (індивідуальна, для пар, сімейна або групова). Важливо зазначити, що для більшості зацікавлених осіб відповідне лікування необхідне для створення умов повноцінного життя, а тому має бути адаптоване до потреб людини 3 метою забезпечення можливості досягнення позитивних результатів.

Водночас, незважаючи на значення ефективної медичної допомоги особам, які бажають здійснити трансгендерний перехід, для забезпечення їм гармонійного розвитку, важливою проблемою $є$ доступ до відповідної терапії, який зазвичай обмежений досягненням 18-річного віку.

Не можна не зазначити забезпечення права трансгендерних осіб і в юному віці на отримання лікування для гальмування процесу досягнення статевої зрілості, консультування 3 питань здійснення трансгендерного переходу, яке гарантовано законодавством деяких закордонних країн, зокрема Нідерландів, Бельгії, Німеччини. Скориставшись наданими правами, відповідні особи після досягнення повноліття за наявності бажання можуть пройти процедури зміни (корекції) статевої належності.

Проте така ситуація 3 доступом до медичної допомоги трансгендерних осіб склалася не скрізь. За висновками «Трансгендерного євродослідження», 80\% трансгендерних людей у СС відмовляють у державному фінансуванні гормональної терапії, пов'язаної із трансгендерним переходом, 86\% таких осіб не можуть отримати державне фінансування проведення операції зі зміни (корекції) статевої належності, у результаті чого більше $50 \%$ 
трансгендерів, які все ж таки наважуються на відповідне оперативне втручання, оплачують медичні послуги самостійно.

На жаль, будь-якої більш-менш офіційної статистики щодо ситуації 3 державним фінансуванням медичної допомоги особам, які здійснюють трансгендерний перехід, у країнах, які не входять до $€ C$, немає. Проте можна з високим відсотком вірогідності стверджувати, що більшість із них не виділяє державних дотацій на реадаптивне лікування або оплачує відповідну медичну допомогу лише частково, що очевидно суперечить нормам, установленим Свропейським судом 3 прав людини ${ }^{8}$, які закликають держави розвивати систему медичного страхування для покриття витрат на лікування, зумовлене «медичною необхідністю», зокрема й операції зі зміни (корекції) статевої належності.

Так, наприклад, ЄСПЛ у справі «Шлумпф проти Швейцарії» встановив, що відмова страхової компанії покрити вартість операції зі зміни статі клієнта у зв'язку 3 недотриманням ним вимоги про спостереження у психіатра не менше двох років для встановлення наявності «істинного транссексуалізму» порушує ст. 8 Свропейської конвенції про захист прав людини і основоположних свобод 1950 р. Національні суди відхилили вимоги заявниці про скорочення цього терміну, навіть незважаючи на те, що було представлено експертний висновок в обгрунтування іiі позиції. ССПЛ повторив висловлені раніше судження про те, що встановлення медичної необхідності заходів із корекції статі не є предметом юридичного визначення.

Аналогічні висновки були сформульовані ЄСПЛ і у справі «Ван Кюк (Van Kuck) проти Німеччини», у якій Суд констатував порушення ст. ст. 6 i 8 Конвенції в ситуації, коли транссексуальній жінці було відмовлено у відшкодуванні понесених нею витрат на гормональну терапію і хірургічні операції з корекції статі. Основні аргументи судових органів Німеччини полягали в тому, що понесені заявницею витрати не можуть розглядатися як витрати на необхідне медичне лікування, оскільки остання сама «спричинила» власне захворювання. ЄСПЛ зазначив, що визначення необхідності проведення медичних втручань у разі транссексуальності питання медичного, а не юридичної розсуду (водночас тягар доведення необхідності такого лікування не може бути покладений на заявницю). Крім того, не можна було стверджувати, що в рішенні заявниці піддатися хірургічній корекції статі було що-небудь довільне або дивне, до того ж у подальшому хірургічні втручання фактично були проведені.

\footnotetext{
${ }^{8}$ Права человека и гендерная идентичность : Тематические доклады Комиссара по правам человека. 2009. URL: https://www.coe.int/t/commissioner/Source/Genderidentity_ru.pdf.
} 
У справі “L. проти Литви» ССПЛ також встановив порушення державою ст. 8 Свропейської конвенції про захист прав людини і основоположних свобод 1950 р., оскільки в литовському законодавстві була прогалина: не було положень, що регламентують проведення операцій щодо цілковитої зміни статі. Аж до ухвалення закону в Литві не були доступні відповідні медичні послуги. Як зазначив ЄСПЛ, бюджетні труднощі у сфері охорони здоров'я могли виправдовувати деяку затримку в забезпеченні потреб транссексуалів, але не затримку в чотири роки. 3 огляду на те, що число зацікавлених осіб обмежене, навантаження на бюджет не могло бути дуже значним, а тому держава-відповідач протиправно не змогла встановити справедливу рівновагу між суспільним інтересом і правами заявника.

Дійсно, транссексуальні люди потребують надзвичайно різноманітних видів медичної допомоги для подолання / максимального пом'якшення дискомфорту / дистресу, що пов'язані 3 розбіжністю між статевою ідентичністю індивіда і статтю, встановленою йому за народження, допомоги ендокринологів, сексологів, психіатрів, хірургів та інших лікарів, яка може бути забезпечена тільки за умови наявності кваліфікованих фахівців. Спеціальний доповідач $\mathrm{OOH}$ із питання про право кожної людини на найвищий досяжний рівень фізичного і психічного здоров'я відзначав, що «медичні працівники повинні усвідомлювати і враховувати особливі потреби транссексуалів і інтерсексуалів». Однак варто зазначити, що в сучасних реаліях у деяких країнах може функціонувати лише одна клініка, яка забезпечує лікування трансгендерних людей, водночас перешкоди на шляху нових досліджень i, потенційно, підвищення якості медичного обслуговування, свідомо не усуваються.

На міжнародному рівні закріплений чи не основний принцип регулювання суспільних відносин у демократичному суспільстві, яким $\epsilon$ рівність. Принцип рівноправності передбачає, що трансгендерні люди мають такі ж права, як і будь-які інші. Це означає, що на них поширюється дія Загальної декларації прав людини, ухваленої Організацією Об'єднаних Націй у 1948 р.

Такі права, як право на життя, на особисту свободу і недоторканність, на рівність перед законом і захист від дискримінації, на приватне життя, на свободу переконань, слова і зібрань, на працю, відпочинок, освіту, медичну допомогу, - усе це також стосується трансгендерів. Однак на практиці, на жаль, становище трансгендерних осіб у більшості країн світу далеке від дотримання всіх цих прав.

Значний відсоток трансгендерних людей стикаються 3 дискримінацією, стигматизацією у зв'язку з неприйняттям їх гендерної ідентичності або гендерних проявів. I положення Загальної декларації прав людини не 
можуть вирішити дану проблему, оскільки визначають права людини загалом, не дають детальних трактувань їх змісту та механізму забезпечення, особливо в аспекті їх реалізації окремими категоріями людей.

Тому у 2006 р. групою експертів ООН були розроблені Принципи застосування міжнародно-правових норм про права людини стосовно сексуальної орієнтації та ґендерної ідентичності (Принципи Джокьякарти).

Так, даним міжнародно-правовим актом гарантовано право кожної людини на найвищий досяжний рівень фізичного та психічного здоров'я без дискримінації за ознакою сексуальної орієнтації або гендерної ідентичності. Для забезпечення даного права держави зобов'язуються вживати всіх необхідних заходів законодавчого, адміністративного й іншого характеру, забезпечувати всім без винятку доступ до закладів охорони здоров'я, відповідних товарів і послуг, зокрема й у зв'язку із сексуальним i репродуктивним здоров'ям, їхню спрямованість на поліпшення стану здоров'я і задоволення потреб усіх осіб без дискримінації за ознакою сексуальної орієнтації або гендерної ідентичності і з урахуванням цих обставин, а також конфіденційність поводження 3 медичною документацією, що стосується цих обставин.

\section{2. Право трансгендерних людей та членів їхніх сімей на отримання} грошових виплат, соціальних послуг, інших видів соціального захисту

Як зазначалося вище, реалізація права трансгендерних осіб на повагу до приватного i сімейного життя пов'язана не лише із проведенням безпосередньої зміни (корекції) статевої належності, але й з юридичним визнанням відповідного факту державою.

Так, відповідно до п. 2.1 розд. II «Внесення змін до актових записів цивільного стану» Правил внесення змін до актових записів цивільного стану, їх поновлення та анулювання, затверджених наказом Міністерства юстиції України від 12 січня 2011 р. № 96/5, у зв’язку зі зміною (корекцією) статевої належності на підставі відповідної заяви відділом державної реєстрації актів цивільного стану за місцем проживання заявника або за місцезнаходженням Центру первинної медико-санітарної допомоги, лікувально-консультативна комісія якого видала медичне свідоцтво про зміну (корекцію) статевої належності, може бути внесено зміни до актового запису про народження людини, зокрема щодо іїі статі.

Рішення про внесення змін до актового запису про народження шляхом зміни власного імені, по батькові, статі та, за потреби, прізвища людини, у зв'язку зі зміною (корекцією) ії статевої належності ухвалюється на підставі висновку відділу державної реєстрації актів цивільного стану, 
складеного згідно 3 відповідним медичним свідоцтвом про зміну (корекцію) статевої належності, у якому, серед іншого, зазначається обсяг медичного втручання щодо зміни (корекції) статевої належності (ендокринологічна терапія, хірургічне втручання та його обсяги тощо) та інформація про те, з якої на яку статеву належність було проведено зміну (корекцію).

Як повідомляе агентство «Урал-прес-інформ» із посиланням на регіональне відділення Пенсійного фонду, житель Копейська Челябінської області Російської Федерації, який змінив чоловічу стать на жіночу, також вийде на пенсію на п'ять років раніше, оскільки отримає всі привілеї, передбачені для росіянок', що свідчить про створення в Російській Федерації умов не лише для фактичної зміни (корекції) статевої належності, але й для юридичної.

Тобто чинним законодавством України, Російської Федерації визначена процедура «юридичної трансформації» фізичної особи у зв'язку зі зміною (корекцією) ії статевої належності, чого не скажеш про стан відповідного законодавства в більшості закордонних країн.

У багатьох країнах Африки й Азії, де тема трансгендерності слабо вивчена, а часто ще й стигматизована, немає жодних офіційних механізмів переходу. Однак і деякі європейські держави, як-от Франція, Болгарія, Грузія, Литва, досі не мають чіткого законодавчого регулювання визнання гендеру.

Це не обов'язково означає, що в таких країнах у принципі неможливо змінити документи. Зазвичай це питання може бути вирішене через суд, однак, що саме той уважатиме достатньою підставою для такої зміни залежить від суб'єктивної думки суддів, на яку впливають, серед іншого, уявлення про трансгендерність, що задають тон у суспільстві конкретної країни.

У сучасних умовах із 49 європейських держав:

20 - не мають чітко прописаних в законодавстві процедур переходу;

8 - не пропонують можливості змінити гендерний маркер у документах (в основному це карликові держави, у яких питання про таке законодавство могло не порушуватися через відсутність звернень);

37 - вимагають постановки діагнозу;

30 - вимагають медичних втручань у тій чи іншій формі;

23 - вимагають стерилізації (зазвичай мається на увазі хірургічна операцію на статевих органах);

22 - вимагають не перебувати у шлюбі або розлучитися (зазвичай така вимога пов'язана з відсутністю визнання одностатевих союзів);

\footnotetext{
${ }^{9}$ Сменивший пол россиянин выйдет на пенсию раньше. URL: https://lenta.ru/news/2019/04/05/trans/.
} 
33 - не пропонують можливості визнання гендеру для неповнолітніх.

Важливо відзначити, що країни Свропи можна класифікувати за тим, як регламентується там дане питання. У зв'язку із цим виділяють:

1. Держави, які визнають одностатеві шлюби.

2. Держави, що не допускають одностатевих шлюбів, але визнають існування шлюбу, протягом якого один із подружжя змінив стать (Австрія, Німеччина, Швейцарія тощо).

3. Держави, у яких не існує правового врегулювання даного питання.

4. Держави, у яких із даного питання існують чітко визначені заборони ${ }^{10}$.

Так, наприклад, законодавство Голландії передбачає, що особа, яка змінила стать, може подати запит до суду про коригування запису у свідоцтві про ії народження, який може бути задоволено в разі дотримання таких умов: 1) особа не перебуває у шлюбі; 2) стать особи за народження визначена як чоловіча, але заявник не здатний зачати дитину; 3) стать особи за народження визначена як жіноча, але заявниця не здатна виносити дитину; 4) $є$ офіційні висновки експертів про зміну статі. Отже, законодавство Голландії допускає зміну статі особи, але водночас вона (дана особа) не повинна бути одруженою і взагалі має бути не здатною до виконання репродуктивної функції ${ }^{11}$.

Проте існують і держави, де для юридичної зміни статі людиною не створено жодних умов. Так, у справі «І. проти Сполученого Королівства» ЄСПЛ зазначив, що заявниця, яка проживає фактично як жінка, юридично залишається чоловіком, і це завдає їй шкоди в різних сферах життя, де стать має юридичне значення. ЄСПЛ зазначив, що право на повагу до приватного життя, гарантоване ст. 8 Конвенції про захист прав людини і основоположних свобод 1950 p., передбачає і право на встановлення деталей своєї ідентичності, а стать не має визначатися лише хромосомними елементами.

У справі «Крістін Гудвін проти Сполученого Королівства» заявниця, яка змінила стать, скаржилася на відсутність юридичного визнання іiі нової ідентичності, зокрема в питаннях працевлаштування, соціального i пенсійного забезпечення, а також можливості взяти шлюб. ЄСПЛ постановив, що в держави $є$ позитивні зобов'язання, одне з яких - ужиття заходів, що дозволяють визнати зміну статі післяопераційних транссексуалів, для реалізації яких мають бути створені ефективні умови.

Водночас в Україні і більшості закордонних країн залишаються неврегульованими питання юридичних зв'язків трансгендерної особи із

\footnotetext{
10 Туманова Л., Владимирова И. Защита семейных прав в Европейском суде по правам человека. Консультант-Плюс: Версия Проф. / ООО «Инфо Лада». Тольятти, 2011. С. 365.

${ }^{11}$ Правовая система Нидерландов / под ред. В. Бойцовой, Л. Бойцовой. Москва : Зерцало, 2006. С. 56.
} 
членами іiі сім’ї (чоловік / дружина, діти й ін.), що мають значення для окремих видів соціального захисту, зокрема для вирішення питання про призначення пенсії у зв'язку із втратою годувальника, державної соціальної допомоги малозабезпеченим сім'ям, державної допомоги одинокій матері (батьку), надання житлових субсидій тощо.

Як зазначають О. Бухановський і С. Простоєв, у разі зміни статі людина як біологічна одиниця продовжує існувати, утім багато прав, зумовлених статевою належністю, змінюються або втрачаються, унаслідок чого виникає проблема правонаступництва ${ }^{12}$, яка, на переконання М. Стефанчука, полягає насамперед у тому, що жодним нормативно-правовим актом не визначено зміну статі як підставу для правонаступництва, що, безумовно, $\epsilon$ істотним недоліком правового регулювання відповідної сфери суспільних відносин ${ }^{13}$.

На порушення прав людини, гарантованих Конвенцією про захист прав людини і основоположних свобод 1950 р., шляхом визнання виключно статі особи, визначеної під час народження дитини і зафіксованої відповідними документами (свідоцтво про народження, паспорт, свідоцтво про соціальне страхування тощо), звернув увагу і Свропейський суд з прав людини. Зокрема, у рішенні від 23 травня 2006 р. у справі «Грант проти Сполученого Королівства» ${ }^{14}$ ССПЛ констатував порушення права заявниці, яка у 26 років змінила стать із чоловічої на жіночу, на повагу до iii приватного життя (ст. 8 Конвенції) шляхом відмови у виплаті їй пенсії у зв’язку 3 тим, що вона народилася чоловіком і право на отримання відповідної грошової виплати зможе реалізувати виключно після досягнення 65-річного віку.

Судом у рішенні від 11 липня 2002 р. у справі «Крістін Гудвін проти Сполученого Королівства» ${ }^{15}$ також було констатовано, що порівняння біологічних чинників чоловічої та жіночої статі не можуть мати визначальне значення в разі відмови в юридичному визнанні зміни трансгендером статі за допомогою хірургічного втручання. Існують інші важливі чинники: встановлення медико-біологічних та соціальнопсихологічних показань для зміни (корекції) статевої приналежності медичними працівниками різного профілю, надання медичної допомоги,

\footnotetext{
12 Бухановский А., Простоев С. Правовые последствия изменения пола при транссексуальных состояниях. URL: http://mosmedclinic.ru/conf_library/25/2/220.

13 Стефанчук М. Щодо визначення сутності та правових наслідків динаміки фізіологічних індивідуалізуючих ознак фізичної особи. Науковий вісник Академї муніципального управління. Серія «Право». 2015. Вип. 2. С. 295.

${ }_{14}$ Рішення Європейського суду з прав людини у справі «Грант проти Сполученого Королівства» від 23 травня 2006 р. (заява № 32570/03). URL: http://docs.pravo.ru/document/view/19382686/17527860.

15 Рішення Європейського суду 3 прав людини у справі «Крістін Гудвін проти Сполученого Королівства» від 11 липня 2002 р. (заява № 28957/95). URL: http://docs.pravo.ru/document/view/19383100/.
} 
зокрема i шляхом хірургічного втручання, 3 метою максимального наближння конкретної особистості, наскільки це можливо, до статі, до якої, на переконання таких осіб, вони належать, а також опанування конкретним трансгендером тієї соціальної ролі, яка притаманна набутій ним статі. ЄСПЛ було зроблено висновок, що з урахуванням названих критеріїв людина, яка змінила стать, повинна розглядатися виключно як особа тієї статі, яка була набута після лікування.

3 огляду на виникнення наслідків зміни (корекції) статі виключно для трансгендерної особи, законодавство України можна вважати таким, що відповідає європейській політиці та практиці ЄСПЛ у цій сфері, оскільки внесені до актового запису про народження зміни є підставою для видачі «нового» свідоцтва про народження із зазначенням зміненої статі, яке в подальшому стане підставою для заміни інших документів особи, внесення змін про неї до відповідних реєстрів, зокрема й у сфері соціального захисту.

Проте невирішеними залишаються питання, чи зберігає особа, яка змінила стать, права, пов'язані із сімейними відносинами та відносинами свояцтва.

Наприклад, відповідно до ст. 36 Закону України «Про загальнообов'язкове державне пенсійне страхування» від 9 липня 2003 р., за загальним правилом пенсія у зв'язку із втратою годувальника призначається непрацездатним членам сім'ї померлого годувальника, які були на його утриманні, за наявності в годувальника на день смерті страхового стажу, який був би необхідний йому для призначення пенсії за III групою інвалідності. Такими непрацездатними членами сім’і вважаються, зокрема: чоловік (дружина), батько, мати, якщо вони є особами 3 інвалідністю або досягли пенсійного віку; діти померлого годувальника, які не досягли 18 років або старші цього віку, якщо вони стали особами з інвалідністю до досягнення 18 років; чоловік (дружина), а в разі їх відсутності - один із батьків або брат чи сестра, дідусь чи бабуся померлого годувальника незалежно від віку і працездатності, якщо він (вона) не працюють і зайняті доглядом за дитиною (дітьми) померлого годувальника до досягнення нею (ними) 8 років.

Під час звернення до органів Пенсійного фонду із заявою про призначення пенсії у зв'язку із втратою годувальника, відповідно до п. 2.3 розд. II «Документи, необхідні для призначення, перерахунку пенсії, поновлення виплати раніше призначеної пенсії, переведення з одного виду пенсії на інший» Порядку подання та оформлення документів для призначення (перерахунку) пенсій відповідно до Закону України «Про загальнообов'язкове державне пенсійне страхування», затвердженого 
постановою Правління Пенсійного фонду України від 25 листопада 2005 р. № 22-1 ${ }^{16}$, крім документів про стаж i заробітну плату померлого, додаються також копії документів, що засвідчують родинні стосунки члена сім'ї з померлим годувальником, якими, зокрема, $\epsilon$ свідоцтво про народження, свідоцтво про шлюб тощо.

Доцільно зауважити, що внесення змін до актового запису про народження трансгендерної особи у зв’язку зі зміною (корекцією) іiі статевої належності не $\epsilon$ підставою для внесення відповідних змін до актових записів про народження ії̈ дітей, про шлюб даної особи, укладений до зміни (корекції) статевої належності тощо, у зв'язку із чим 3 юридичного погляду чоловік/дружина та діти трансгендерної особи не $\epsilon$ членами iï сім'ї, оскільки з огляду на висновки ЄСПЛ правовий статус людини, яка змінила стать, має розглядатися виключно через сукупність ознак, прав та обов'язків особи тієї статі, яка була набута після лікування. За таких умов, без застосування юрисдикційної форми захисту права на пенсійне забезпечення у зв'язку із втратою годувальника члени сім'ї (чоловік/дружина та діти) трансгендерної особи в сучасних умовах позбавлені можливості реалізувати відповідне право на отримання вказаних грошових виплат.

\section{ВИСНОВКИ}

У сучасних умовах трансгендерні особи обмежені у праві на соціальний захист. Так, право на доступ до зміни статі має включати розумний вибір наявних медичних центрів, а витрати повинні компенсуватися відповідно до національних правил охорони здоров'я. Водночас якість лікування трансгендерів часто не підходить навіть близько до «найбільш високих досяжних стандартів здоров'я», а іноді таке лікування призводить до довічної фізичної травми. Багато трансгендерних людей, які йдуть на операцію зі зміни статі, змушені виїжджати за кордон, стикаючись водночас із величезними труднощами, пов'язаними з фінансуванням своїх витрат. Загалом така ситуація створює нерівність у доступі до охорони здоров'я всередині країни і між країнами.

Незважаючи на здавалось би максимально виважене та якісне нормативно-правове регулювання надання медичної допомоги трансгендерним особам, варто зазначити, що практика реалізації в Україні відповідних положень законодавства $є$ недосконалою. Передусім медикобіологічними показаннями для зміни (корекції) статевої належності $\epsilon$

\footnotetext{
${ }^{16}$ Про затвердження Порядку подання та оформлення документів для призначення (перерахунку) пенсій відповідно до Закону України «Про загальнообов'язкове державне пенсійне страхування» : постанова Правління Пенсійного фонду України від 25 листопада 2005 р. № 22-1. Офіиійний вісник Украӥни. 2005. № 52. Ст. 3383.
} 
наявність у людини психічного і поведінкового розладу «транссексуалізм», у разі встановлення якого здебільшого трансгендерні люди стикаються 3 повним нерозумінням лікарів-психіатрів, тому не можуть отримати бажаний консультативний висновок, що $є$ підставою для відмови у видачі медичного свідоцтва про зміну (корекцію) статевої належності.

Крім того, в Україні дуже мало лікарів-спеціалістів, які мають знання саме щодо питань практичного застосування уніфікованого клінічного протоколу «Гендерна дисфорія», у зв'язку із чим на практиці трансгендерні люди змушені звертатись по юридичну допомогу з питань обмеження їхніх прав в обранні лікувального закладу та лікаря, який може надати психіатричну допомогу та встановити правильний діагноз.

Досить часто люди, які вже здійснили трансгендерний перехід, уникають звернення до лікарів через побоювання нерозуміння, неповаги й іншого негативу на свою адресу з боку медичного персоналу. Крім того, в Україні та більшості держав світу немає кваліфікованого медичного персоналу, здатного надавати медичну допомогу та послуги трансгендерам у разі такої потреби, не пов'язаної зі зміною (корекцією) статевої належності, з огляду на особливості їхньої фізіології.

Обмежені у праві на соціальний захист також члени сім'ї трансгендерних осіб, які юридично втрачають правовий зв'язок із родичем, який змінив (скоректував) статеву належність. Ефективним способом забезпечення реалізації права на соціальний захист членів сім’ї трансгендерної особи буде встановлення в порядку окремого провадження факту, який має юридичне значення, що особа, записана батьком/матір'ю, чоловіком/дружиною заявника, та трансгендерна особа $є$ тотожними.

На жаль, 3 огляду на відсутність відповідних судових рішень у національній юридичній практиці, зокрема й через незначну кількість проведених медичних втручань в організм людини з метою зміни (корекції) статевої належності та порівняно незначний проміжок часу, що пройшов із моменту впровадження відповідної практики в Україні, неможливо проаналізувати їхній зміст і обгрунтування можливості/неможливості встановлення відповідних фактів. Водночас цілком очікуваними є дилеми, що постануть перед національними судами, щодо надання пріоритету відновлення права на соціальний захист членів сім'ї трансгендерної особи чи дотримання засад регулювання сімейних відносин.

Фактично, за сучасного стану регулювання сімейних відносин та відносин соціального захисту, у разі задоволення судом заяви про встановлення тотожності особи, записаної батьком/матір'ю, чоловіком/ дружиною заявника, та трансгендерної особи, з метою, наприклад, отримання заявником пенсії у зв'язку із втратою годувальника, судом 
будуть порушені норми ст. 21 Сімейного кодексу України, відповідно до якої шлюбом $є$ сімейний союз жінки та чоловіка, ст. 121 Сімейного кодексу України, якою передбачено, що права й обов'язки матері, батька i дитини грунтуються на походженні дитини від них, оскільки фактично буде встановлена можливість існування одностатевих шлюбів та наявність визнаних державою батьківських (рос. мовою «родительских») прав i обов'язків щодо дитини в одностатевих партнерів.

\section{АНОТАЦІЯ}

Стаття присвячена дослідженню теоретичних та практичних проблем забезпечення права на соціальний захист трансгендерних людей та членів їхніх сімей в Україні й окремих закордонних країнах.

У статті розкриваються основні проблеми здійснення трансгендерними людьми права на медичну допомогу. Виявлено, що основними проблемами людей, яким встановлено діагноз «гендерна дисфорія», у сфері охорони здоров'я $є$ низька якість медичних послуг, що надаються, не охоплення їх програмами державного фінансування, обмежена мережа закладів та спеціалістів, що їх надають, значна стигматизація трансгендерних людей сторони медичним персоналом лікувально-профілактичних закладів.

Розкриваються проблеми доступу людей, яким змінено (скоректовано) гендерну належність, та членів їхніх сімей до системи заходів соціального захисту у виді грошових виплат, соціальних послуг, соціальних пільг, натуральної допомоги тощо. Встановлено, що для більшості країн світу ключовою проблемою в цій сфері є відсутність ефективного механізму юридичної трансформації трансгендерної особи у зв'язку зі зміною її статі. Доведено, що в Україні люди, які змінили стать, фактично не обмежені у здійсненні права на соціальний захист, оскільки в нашій державі таким особам забезпечена можливість внесення змін до актового запису про їх народження, що в подальшому стане підставою для зміни всіх документів, що стосуються особи трансгендерної людини. На підставі дослідження стану дотримання прав трансгендерних осіб в інших країнах зроблено висновок, що здебільшого в інших державах світу люди, які змінили статеву належність, обмежені у праві на працю та праві на соціальний захист, оскільки державою їхня стать, змінена після проведення операції, не визнається.

Встановлено, що майже в усіх країнах світу обмежені у праві на «сімейні види» допомог у сфері соціального захисту члени сім'ї трансгендерних осіб, оскільки в жодній державі законодавством не передбачено можливості на підставі документів про зміну (корекцію) статевої належності людини внесення змін до актових записів про 
народження ії дітей, про шлюб трансгендерної особи, укладений до зміни (корекції) іiї статевої належності, у зв'язку із чим з юридичного погляду чоловік/дружина та діти трансгендерної особи не є членами іiі сім'ї, оскільки з огляду на висновки ЄСПЛ правовий статус людини, яка змінила стать, має розглядатися виключно через сукупність ознак, прав та обов'язків особи тієї статі, яка була набута після лікування.

\section{ЛІТЕРАТУРА}

1. Малеина М. Изменение биологического и социального пола: перспективы развития законодательства. Сейчас.ру : бизнес-издание. Новости России и мира. 2017. URL: https://www.lawmix.ru/comm/4721.

2. Шалиганова А. Щодо правової природи та змісту права на гендерну ідентичність. Право і безпека. 2011. № 3 (40). С. 274-279.

3. Калайтанова Н. Смена пола. Повторный процесс социализации трансгендеров. Проблемы и перспективы развития гуманитарных и сочиально-экономических наук : сборник научных трудов по материалам Международной научно-практической конференции. 2017. Ч. 3. С. 30-33.

4. Commissioned and published by Thomas Hammarberg. Council of Europe Commissioner for Human Rights. 29.07.2009. URL: https://wcd.coe.int/ ViewDoc.jsp?p=\&id $=1588227 \&$ Site $=$ COE $\&$ direct $=$ true.

5. Про заходи з боротьби проти дискримінації за ознаками сексуальної орієнтації або гендерної ідентичності : Рекомендація CM/Rec (2010) 5 Комітету міністрів Ради Європи державам-членам. Медичне право. 2014. № 1. С. 66-75.

6. Глобальних рух за гендерну рівність. Англійський переклад аргентинського Закону «Про гендерну ідентичність». URL: http://globaltransaction.files.wordpress.com/2012/05/argentina-gender-identitylaw.pdf.

7. Про затвердження та впровадження медико-технологічних документів зі стандартизації медичної допомоги при гендерній дисфорії : наказ Міністерства охорони здоров’я України від 15 вересня 2016 р. № 972. URL: https://dec.gov.ua/wp-content/uploads/2019/11/2016_972_ykpmd_gendysfor.pdf.

8. Права человека и гендерная идентичность : Тематические доклады Комиссара по правам человека. 2009. URL: https://www.coe.int/t/ commissioner/Source/Genderidentity_ru.pdf.

9. Сменивший пол россиянин выйдет на пенсию раньше. URL: https://lenta.ru/news/2019/04/05/trans/.

10. Туманова Л., Владимирова И. Защита семейных прав в Европейском Суде по правам человека. Консультант Плюс : Версия Проф. / ООО «Инфо Лада». Тольятти, 2011. 
11. Правовая система Нидерландов / под ред. В. Бойцовой, Л. Бойцовой. Москва : Зерцало, 2006.

12. Бухановский А., Простоев С. Правовые последствия изменения пола при транссексуальных состояниях. URL: http://mosmedclinic.ru/ conf_library/25/2/220.

13. Стефанчук М. Щодо визначення сутності та правових наслідків динаміки фізіологічних індивідуалізуючих ознак фізичної особи. Науковий вісник Академії муніципального управління. Серія «Право». 2015. Вип. 2. C. 289-297.

14. Рішення Свропейського суду з прав людини у справі «Грант проти Сполученого Королівства» від 23 травня 2006 р. (заява № 32570/03). URL: http://docs.pravo.ru/document/view/19382686/17527860.

15. Рішення Свропейського суду 3 прав людини у справі «Крістін Гудвін проти Сполученого Королівства» від 11 липня 2002 р. (заява № 28957/95). URL: http://docs.pravo.ru/document/view/19383100/.

16. Про затвердження Порядку подання та оформлення документів для призначення (перерахунку) пенсій відповідно до Закону України «Про загальнообов'язкове державне пенсійне страхування» : постанова Правління Пенсійного фонду України від 25 листопада 2005 р. № 22-1. Офіиійний вісник України. 2005. № 52. Ст. 3383.

\section{Information about authors:} Voloshyna S. M.,

$\mathrm{PhD}$ in Law, Associate Professor, Associate Professor of the Department of Labor Law and Social Security Law National University "Odessa Law Academy" 23, Fontan road, Odessa, 65000, Ukraine Borychenko K. V., $\mathrm{PhD}$ in Law, Associate Professor of the Department of Labor Law and Social Security Law National University "Odessa Law Academy" 23, Fontan road, Odessa, 65000, Ukraine 